\title{
Musical Excellence: The Spiritual Panacea of the Future
}

\author{
Cristian Caraman
}

\begin{abstract}
The present paper presents The biblical reference points of music, The manifestations of Protestant music culture and The excellence in music. The Protestant music started with Luther, Calvin and continued with Bach, Handel, Brahms, asserting itself in Europe, North America, Africa, and recently in Asia. The Protestant culture, especially the musical one, has penetrated all aspects of civilization, being by far, through its representatives, one of the most powerful spiritual dimensions in human history. The future of a better world consists of a more educated and more sensible generation in which music can make people better. The values of the Protestant-Evangelical music can contribute to the human spiritual dimension and to the beauty of its culture and civilization. KEY WORDS: culture, music, religion, Bible, Protestantism.
\end{abstract}

\section{The Biblical Reference Points of Music}

Through music, future generations of young people will develop different attitudes toward society and will be able to discover the benefits of art. Furthermore, the groups they are part of will stand out easier and they will become the artist of the future. Music is a vibration. The young voice student will first learn how to breathe correctly and only then how to sing. The study of violin will best develop their hearing, and the study of guitar will gain the student more self-confidence and will gain a bigger power of concentration 
then the other young people. The grace of playing the violoncello or the piano will in the same time correct the position of the back. Music can enlarge the educational level of young people, can increase the level of knowledge and can bring spiritual benefits to the future world. The natural world is the creation of God, its beauty being contemplated by humans and artistically enlightened through the works of art. In the Christian art, the human-divine person of Christ has kept His human attributes, art itself being further on, a way of knowing God. The religious theme enjoyed a remarkable attention in the artists' creations, museums and art collections, the musical works and literary writings being a proof in this sense. The entire universal literature was marked by the beauty, form, style and spiritual-philosophical depth of the writings included in The Holy Scriptures, beginning with the historic and poetic writings, and ending with the epistolary and prophetic ones. Music has its genesis in the Bible, and the references about the organization of the choral or instrumental bands, the description of the musical instruments, critical appreciations on the way of interpreting some songs and many other impressions about singing were always edifying for musicians. Besides, the precision and the accuracy of the descriptions regarding different sacred constructions (The Tent Meeting, The Temple of Jerusalem) or civil buildings, and the description of the priest clothing or of the interior of the Temple are worth taking into consideration by any architect, designer, painter or sculptor. For archeologists, the Bible represents an endless source of information regarding the civilizations from the old times, different buildings or preserved remains, fortresses walls, pottery, metal pieces and inscriptions on stone, clay, paper and other materials which can be considered historical remnants. The accuracy of the Scripture regarding the geographic data and historic events brings broad evidence for the researchers in this domain for harmonizing the problems of interpretation of the historic data with the biblical ones, and for correcting the errors from both domains. For sociologists, political scientists and financiers the information about the financial, political and social problems are important and relevant, along with the detailed rules about papers and ceremonies, which are generously found in the Holy 
books. Likewise, the specialists in the Biology sciences, Zoology and Anatomy can find in the Bible many data about the manifestations of life from an anatomical, physiological or zoological point of view. The researchers of the Universe and of the meteorological phenomena can find in the pages of the Bible important data about the Earth formation, the appearance of life on Earth, about how the air currents circulate, about natural phenomena - thunderbolt, rainbow, rain, hail, snow-about the fact that the Earth is round, about planets and their movement in the Universe and about many natural phenomena. In the Bible we find discoveries, information and practical lessons about the way of behaving in family and society, about how to relate to people, about how to win the battles of life, and about the fascinating history of the mankind culture. Its message comes towards us from the time of the past centuries, and the source of inspiration ascends until the eternity days. On its pages we come across "the civilizations which have succeeded on the face of Earth bringing into the world the idea of eternity. Our culture began with The Psalter and The Homiliary." ${ }^{1}$ The role of the Bible in society is overwhelming, having an important role in the affirmation and development of the human society culture. Music can keep the young people away from the day to day dangers, like computers addiction, gadgets, television.

\section{The Manifestations of Protestant Music Culture}

Starting with the sixteenth century, the Protestant church created a simple, traditional music, which could edify the local congregations. The Protestant hymns reflected the ideology of the Reform, ${ }^{2}$ having roots in the religious monody of the Hebrew and Gregorian song and in the Hussite songs, the musical creations of the Meistersängerilor or in the old songs with Latin text. The Protestant music strongly asserted itself in France through the Huguenot choral-psalm, in Germany through the Lutheran choral, in The Netherlands, Italy, Poland through Psalters and sacred songs collection, in England through anthems and Anglican verse-anthem, until the end of the eighteenth century. The Lutheran Choral has 
evolved from the monadic form up to the motet, cantata and suite during the sixteenth and seventeenth centuries. The Lutheran Chorals composed by Luther and Johann Walter, Albert Erasmus, Johann Gramann or Elisabeth Cruciger formed the Wittenberg orbit collection. The Bohemian brothers published the collection with the autochthonous hymns Ein new Gesang Buchlen (1531). At Strasbourg and Konstanz the Calvin ministers Johannes Zwick, Amrosius Blarer and Thomas Blarer edited the volume with Calvin Chorals Nuw Gsangbuchle (Zürich, 1536). In the Counter reform period, the repertoire of the Protestant music strengthened with the appearance of the hymns arranged by Johannes Keuchenthal in Kirchen Gesange latinisch und deudsch (Wittenberg, 1573) and by Nikolaus Selnecker in Christiliche Psalmen, Lieder und Kirchengesange (Leipzig, 1587). During the 30 years war (16161648), the Protestant music had as its main theme the affirmation of the Protestant creeds and personal beliefs. Among the Protestant composers of Post-Reform period there are Selnecker, Paul Eber (1511-1569), Ludwig Helmbold, Bartholomäus Ringwaldt (15301599) and Martin Schalling (1532-1600), in their works being distinguished the ideals of the Lutheran Humanism. In the Baroque period, Lucas Osiander (1534-1604) introduces the harmonization of the chorals on 4 voices with the melody in descant at tenor, in the collection Funfzig geistliche Lieder und Psalmen (Nurenberg, 1586), with the intention to encourage the congregational singing with the accompaniment of the choir. In the seventeenth century the texts are written by well-known poets and the harmonization at 4 voices of the songs is made by acknowledged composers like Bartholomäus Gesius (Heut triumphieret Gottes Sohn, Asuf meinen lieben Gott and Befehl du deine Wege), Melchior Vulpius (Gelobt sei Gott), Hans Leo Hassler, Christoph Knolkl (Herzlich tut mich verlangen, 1605) or Paul Gerhardt (O Haupt, 1647). Cornelius Baker introduces in German Psalter(1628) melodies of Heinrich Schütz (1585-1672). The most important composer of the Baroque period remains Johannes Gruger, cantor at Saint Nicolai church from Berlin (1657), whose songs are distinguished by melodic simplicity, expressive declamation and rhythmic flexibility. In Gruger's collections (Neues vollkomliches Gesanbuch, 1640 and 
Trostlieder) the songs are harmonized at 4 voices and figurative bass with accompaniment at keyboard, intended for private religious services and organ accompaniment for church. In the Pietism period (1675-1750), the Protestant music gains artistic maturity. After 1700 the books of hymns were written both for the congregation, in which the songs had new texts, and for the organist which contained songs with figurate bass and only the first words of the text, the theme of the new Protestant hymns being based on emphasizing the personal belief, spiritual renascence and penance of the worshippers. Among the Lutheran Orthodox composers are Paul Gerhart (Ich steh an deiner Krippehier), Johannes Schroder (Eins is not), Johannes Sebastian Bach (1685-1750), Telemann Georg Philipp (1681-767), Johann Balthasar Kőnig (1691-1758), the last two compiling the biggest collection from the eighteenth century (Harmonischer Lieder-Schatz, Frankfurt, 1738). J.S. Bach, considered to be the greatest composers of all times, wrote songs original for choral as well as vocal and instrumental compositions in which he introduced the Lutheran choral. The Harmonized Choral of Bach represents the pick of the Cantionalsatz tradition in the history of the Protestant music after the Reform period, inspiring the sense of spiritual greatness to the generations of musician who followed, up to the present days. In the Enlightenment period (1750-1810) the texts of the protestant music are rewritten or modified and the songs are harmonized to 4 voices on 2 staffs. The songs of this period are characterized by pathos and simplicity and the texts belong to well-known poets like Friedrich Gottlieb Klopstock, Mathias Claudius (1740-1815) or C. F. Gellert whose Geistliche Oden und Lieder (1757) was put on music by Carl Philipp Emanuel Bach (1714-1788), Franz Joseph Haydn (1732809), Johann Joachim Quantz (1697-1773) or Johann Philipp Kirnberger (1721-1783). The modern Protestant music from the nineteenth century is characterized by the restoration movement of the Lutheran Choral Patrimony and the renewal of the Lutheran liturgy, fact which led to the authorized neatness of the German Protestant hymnology. The patriotic devotion of the composers and musicians like Ernst Moritz Arndt (1769-1860) stimulated the appearance of new Protestant musical compositions. In 
1815 appeared the hymnology entitled Deutsches Evangelisches Gesangbuch followed in 1950 by Evangelisches Kirchengesangbuch with 394 Protestant Liturgy Chorals. In the twentieth century the interest of the poets in the Protestant song develops, these writing texts for the Lutheran hymns, among them being Jochen Klepper (1903-1942), Otto Reithmuller (1889-1938) or R. A. Schrőder (1878-1962). Starting with 1930 the German composers recreated and reformed the Protestant hymnology, reviving the composition procedures of the Contrafactum from the sixteenth century, of transcription and adaptation of the biblical texts at the existing songs. Fritz Werner, Johannes Petzold and others rewrite the texts for the Protestant Chorals, introducing the clerical modes and the metric forms in writing the chorals. The hymnology Evangelisches Gesangbuch (1950) contains traditional German Chorals, new chorals and hymns of new congregations. In the present hymnologies "there are included hymns which belong to the regional churches, and some texts and songs are outside of the traditional choral, in this sense having to take into account the problem of the significance of the modern choral against the Protestant choral from the sixteenth century." ${ }^{3}$ The Protestant choral remains the biggest accomplishment of the Reform period in the music domain, influencing the universal music, beginning with the sixteenth century and associating the Protestant belief a new way of execution, The Congregational singing (common). Until nowadays, 20 types of chorals are known, starting with the monadic form and up to cantata and choral-suite.

Regarding the Protestant Hymn, it undergoes an ample development in different traditions, being an important part of the congregational praying. J. S. Bach harmonized on 4 voices many of the Protestant hymns, introducing them in his works. The English and Scottish Protestants, which were under the influence of Lutheranism introduced hymns in their Anglican and methodic liturgy. The book of hymns of Miles Coverdale, Psalmes and Spiritual Songs (1543) is based on the hymnology from Wittenberg. Thomas Cranmer included 24 Latin hymns in Book of Common Prayer. Until the eighteenth century the English hymn developed into a form close to the German choral. The book of hymns The Hymnes 
and Songs of the Church (1623) of George Wither contains hymns for the services officiated on holidays or special occasions. Isaac Watts (1674-1748) reestablishes the place of the Protestant hymn according to the principle by which the congregational song could be the expression of the worshippers reflections and feelings. The Calvin Psalter contained in the beginning hymns-psalms in syllabic style, after that, in the eighteenth century the hymns being written in polyphonic imitative style with instrumental accompaniment and in diatonic modes of major-minor. American hymns have been influenced by the modal construct of the autochthon popular song; the development of notation created the opportunity of publishing psalms, hymns and anthems in collections like Southern Harmony (1835) by William Walker and The Sacred Harp (1844) by E. J. King. John Wesley (1703-1791) and Charles Wesley (1707-1788) represent an important stage in the history of the Protestant hymnology, in which the text reflects the expression of the personal emotion of the Protestant believers. Wesley puts the hymn in the centre of the evangelic prayer, many of the hymns being in trochaic meter (Jesus, lover of my soul). The collection of hymn of J. F. Lampe (1746) contains 24 hymns by Ch. Wesley, being the first collection of Methodist hymns from England. Another book of hymns was Sacred Melody (1761), the hymns being written in a gallant style, similar to the concert music, sometimes adapted after the secular hymn. In the nineteenth century, the Protestant hymn and the medieval religious hymn had a flourishing development, reflected in the collection Hymns Written and Adapted to the Weekly Chrch Service of the Year (1827) of Bishop Heber. Surnamed the creator of the modern book of religious hymns, Heber conceived the new Protestant hymnology like being necessary to the liturgical functions and to the annual religious calendar. The Evangelic tradition of the Protestant hymn records the collection Hymnal Noted (1851-1854), Christian Psalmody (1833), Selection of Psalms and Hymns (1853), Psalms and Hymns (1858), Chorale Book for England (1863). In America the Protestant hymns were brought by Dwight L. Moody and Ira D. Sankey. In The English Hymnal (1906) there were introduced for the first time folk songs along with the Gallic Methodist hymns and songs written by Philip P. Bliss and Ira 
Sankey. In 1925 it appears Songs of Prayer, mostly ecumenical, both in spirit and in hymnist construction. After 1960 the Protestant hymn passes through a transformation and a modern renewal. The charismatic movement encouraged a common style of singing, free and without formalism, with a very expressive musical and poetic language, feelings being stimulated. The songs are repeatable and simple, easy to memorize and sing, many of them anticipating the soul and rock. The guitar and the electronic keyboard begin to replace the organ. The new musical forms of the evangelic hymn are known under the name of worship songs. The Baptist Church, The Reformed United Church and The Scottish Church edited reviewed editions of devotional hymns, the moment being known as The Explosion of the Hymn. In the collection Hymns for Today's Church (1982) old hymns are included, from which the archaisms, the songs stimulating the religious feeling and the respect for God, were removed. In America the Protestant congregations sang for two centuries the psalms and the European hymns until they developed their own devotional hymns. Towards the end of the eighteenth century appeared the first composers formed at the American universities who wrote and published the books of the American congregational hymns like Union Harmony (1793), Kentucky Harmony (1816), Missouri Harmony (1820), Southern Harmony (1835) or The Sacred Harp (1844). After 1800, in the south and centre of the North-American continent, appeared the folk hymns, known as Spiritual Songs, made up of couplet and having texts strongly expressive which sometimes repeat themselves. The first collection of Afro-American hymns, Negro-spiritual, appeared after the Civil War, the enthusiastic style of the songs and of the texts exceeding the sober and balanced one of the hymns and traditional metric psalms. The songs have a popular language, often modal, the musical scales are different, typical to the American folklore. In 1784 and 1798 Joshua Smith edited Hymns and spiritual Songs. In North America, Lowell Mason, Thomas Hastings composed hymns after European models, like Antioch based on themes from Messiah by Händel or Christian Lyre (1831) in which Joshua Leavitt includes texts of secular hymns. Starting with the nineteenth century, devotional hymns are edited in a large quantity, the tradition of 
evangelic music continuing in the twentieth century with the gospel hymn. The songs composed by Philip .B. Bliss, Ira D. Sankey, James McGranaham and George C. Stebbins were published in Gospel Hymns, 1-6 Complete (1894). Among the composers of gospel from the twentieth century there are Charles McCallon Alexander, Homer Rodeheaver, Charles H. Gabriel author of the hymn I stand amazed in the presence (1905), Charles A. Tindley with We'll understand it better by and by (1905) and Thomas A .Dorsey with Precious Lord, take my hand (1932), the last two composing in Afro-American tradition (black-gospel). In the twentieth century the American hymnology develops in ecumenical tradition, including hymns like Joyful, joyful, we adore thee by Henry Van Dyke, written after a song from The Ninth Simfony by L. van Beethoven (1907) or God of grace and God of Glorz by Harrz Emerson Fosdick, written after a Gallic song (1931). Another type of hymn appeared in America, in the first half of the twentieth century, called black national anthem, cultivated by James Johnson Weldon and J. Rosamond Johnson with Lift every voice and sing (1901). After the second half of the twentieth century there began to be distinguished composers of evangelic hymns like Carl Schalk with Naw (1968), Richard Dirkson with Vineyard Haven (1972) or Carlton R. Young with Beginning (1987). The charismatic movement which appeared after 1970 cultivated the miniatural hymn, marked by simplicity and melodic shortness, like Seek ye first (Karen Lafferty, 1971) and encouraged the introduction of scriptural songs. Towards the end of the twentieth century, in the American hymnology were introduced, along with the creation in 1989 of the organization Hymn Society in the United States and Canada, African, Latin-American, Asian and American songs. In Canada the collection of hymns The Hymn Book (1971) was published, the best known ecumenical hymn being $O$ day of God, Ddraw Nigh by Robert B. Y. Scott (1939). The rich and varied content from a musical, emotional and thematic point of view of the Protestant-evangelic music represents a future for the spiritual renewal of mind and soul structure of human being. 


\section{Excellence in Music}

In the twentieth century, the contrast between musical styles remain at a very high level in terms of quality, refinement and compositional talent but also in terms of the purpose or of the idea for which the musical works were written. The critic and composer Hugo Cole notes that what is good for music may be unsuitable for liturgy and vice versa: "Bad music is good if it fosters community spirit in the congregation and raises it to collectively higher spiritual levels." ${ }^{4}$ Reality shows that "the music considered unsuitable for the liturgical service can satisfy the spiritual needs of the congregation. Also, it is equally that religious music played in a concert hall can transform and enrich the spirit and mind of the listener. The main quality of music is represented by its spiritual depth." ${ }^{\prime \prime}$ In the twentieth century the accent in the artistic creation was placed mainly on human feelings. Several Christian artists such as Arvo Pärt (1935-), ${ }^{6}$ suggested a new possibility of art and human expression as part of the universal truth. The profound changes that occurred in the Western culture became passionate and involved in the interpersonal human relations, leaving in turn a very small space for spiritual issues. This shift in spiritual focus will require reconsideration of art and its place in the Church. As a reaction to the emergence of various forms and styles of music, musicians introduced the term of Excellence in Music. The term excellence in music is used by Andrew Wilson-Dickson, meaning an exquisite and professional music, well written according to all the rules of composition. ${ }^{7}$ Where musical excellence is assured, listeners often require efforts to find depth and spiritual sincerity in the worship of God. Modern man focuses on rationality in discovering the truth and is reluctant to past traditions, this being reflected in the way of worship. In the twentieth century, the stylistic diversity provoked different reactions from composers and vocalists but also from the church on what kind of music to be used during its service. Contemporary Christian music has developed gradually in the human civilization, representing the society in its cultural and traditional diversity. The excellent music is the music through which the spiritual human being can engage in a sincere worship. In the 
Eastern and the Western Church music has remained a symbolic form, where worship is the most important Christian manifestation. The archbishop of Canterbury noted in a report in 1990 that "Musical resources must be diversified: congregation, choirs, instruments, styles, cultural and denominational variety-all need to be exploited, with a combination of imagination and understanding of tradition." Over time, the Protestant music has modernized its traditional ecclesiastical forms and genres for the liturgical church functionality. Therefore, these renewals correspond to music appropriate to the spiritual excellence of the future.

\section{Conclusion}

The Christian music contains the reconciliation between traditional and modern music, hence, being an isolated case in terms of styles and forms. The heart of reconciliation in diversity remains the Savior through the commandment: „Teacher, which is the great commandment in the Law?" And He said to him, "You Shall Love the Lord your God with all your heart and with all your soul and with all your mind. This is the great and first Commandment. And a second is like it: You Shall Love your neighbor as yourself." ${ }^{\prime 9}$ The six centuries of Protestant music (if the fifteenth century Pre-Hussite reform is included) are added to the centuries of universal art, created by the wisdom of God and offered to humanity through His creative genius. Good music in the community of faith must be easy to understand and spiritually strong. Mozart wrote to his father about his concerts: "There are passages here and there from which connoisseurs alone can derive satisfaction; but these passages are written in such a way that the less learned will be pleased, though without knowing why."10 Also, Christian music should be sincere, complex and should integrate itself in the cultural needs of the present and of the future. Joseph Gélineau emphasized: "A very simple tune can be dismissed as worthless if taken in isolation but makes a marvellous contribution to the spirit and beauty of the celebration, whereas a great work which is too difficult or badly done can wreck it."11 The religious

musical treasures are of a great importance for humanity, because 
they enhance the understanding of culture and civilization, through Jesus Christ "in whom are hidden all the treasures of wisdom and knowledge." ${ }^{2}$ By the wisdom of God man created many of his material and spiritual values, and also the institutional manner to communicate these values.

NOTES

1 "Prefață" in Biblia sau Sfânta Scriptură, ediția a III-a (Berlin, Ohio: 1944. T.G.S. International P.O.Box 355. 44610, U.S.A). See also, Ioan-Gheorghe Rotaru, Sabatarienii în contextul vie? ii transilvane (sec. XVI-XIX), Vol. I. (Cluj-Napoca: Risoprint, 2014), 316-325, 339-345.

${ }^{2}$ The common features of Protestantism remain: Sola Fide, Sola Scriptura, Solus Christus, Sola Gratia. Cristian Caraman, Genuri ale muzicii protestante (Bucureşti: Universitatea Națională de Muzică, 2011), 15, 16, 39.

${ }^{3}$ Cristian Caraman, Genuri ale muzicii protestante, 74.

${ }^{4}$ 1. Hugo Cole, The Chaging Face of Music (Oxford, 1978), 91. See also Andrew Wilson-Dickson, The Story of Christan Music (Minneapolis: Fortress Press, 1996), 243.

${ }^{5}$ Cristian Caraman, Muzica Protestantă Modernă (București: Universitatea Națională de Muzică, 2011), 108.

${ }^{6}$ Arvo Pärt, originally from Estonia, it is a composer of classical and sacred music. From the late 1970s Pärt is often associated with the minimalist style, which includes his compositional technique tintinnabuli. Pärt was born at Paide. Cf. Arvo Pärt-Wikipedia (https://ro.wikipedia.org/wiki/Arvo_Pärt. Last accessed April 19, 2014.)

${ }^{7}$ Cf. Andrew Wilson-Dickson, The story of Christian Music, 244. See also Cristian Caraman, Muzica Protestantă Modernă, 109.

${ }^{8}$ Academia Regală de Muzică, Comisia Arhiepiscopală pentru Muzica Bisericească (febr. 1920), 23.

${ }^{9}$ Matthew 22: 36-39, The Holy Bible, English Standard Version (London: HarperCollins Religious, 77-85 Fulham Palace Road, HammerSmith, W6 8JB, England. ESV® Text Edition: 2011).

${ }^{10}$ Cf. E. Blom, Mozart Letters, Letter sent by Mozart to his father in 28.12.1782 (Harmonsworth, 1956). See also, Andrew Wilson-Dickson, The Story of Christian Music, 246.

${ }^{11}$ Cf. Joseph Gélineau, The Liturgy Today and Tomorrow (New York, 1978), 90. See also Andrew Wilson-Dickson, The Story of Christian Music, 246.

12 "Colossians 2: 3" in The Holy Bible, English Standard Version (London: HarperCollins Religious, 77-85 Fulham Palace Road, HammerSmith, W6 8JB, England. ESV® Text Edition: 2011). 


\section{SELECTIVE BIBLIOGRAPHY}

Alfred Bertholet, Dicționarul Religiilor (Iaşi: Universitatea "Alexandru Ioan Cuza", 1995).

Alison Latham, The Oxford Companion to Music (Oxford, University Press, 2002).

Andrew-Wilson Dickson, The Story of Christian Music (Fortress Press, Minneapolis, 1996).

W. Apel, The New Harvard Dictionary of Music (Londra: D. M. Randel, 2/1969).

E. Blom, Mozart Letters, Scrisoare trimisă de Mozart tatălui său în 28.12 .1782 (Harmonsworth, 1956).

Cristian Caraman, revista MUZICA (Bucureşti: Uniunea Compozitorilor și Muzicologilor din România, anul XXIII, nr. 2(90), aprilie-iunie 2012) .

Cristian Caraman, "Pasiunea" in Genuri ale Muzicii Protestante (Bucureşti: Universitatea de Muzică, 2011).

Cristian Caraman, Muzica Protestanta Moderna (Bucureşti: Universitatea de Muzică, 2011).

Daniel Brânzei, "Prefață" in Biblia sau Sfânta Scriptură, ediția a III-a, revizuită şi adăugită, 1944

(Berlin, Ohio: T.G.S. International P.O.Box 355. 44610, U.S.A).

Earle Cairns E., Creștinismul de-a lungul secolelor (Oradea: Societatea Misionară Română, 1992).

Hugo Cole, The Chaging Face of Music (Oxford, 1978).

Ioan-Gheorghe Rotaru, Sabatarienii în contextul vie?ii transilvane (sec. XVI-XIX), Vol. I. (Cluj-Napoca: Risoprint, 2014).

Joseph Gelineau, The Liturgy Today and Tomorrow (New York, 1978).

Mark Juergensmeyer, The New Cold War: Religious Nationalism Confronts the Secular State (Berkeley, CA: University of California Press, 1993).

Williston Walker, A History of the Christian Church (New York, Charles Scribner's Sons, 1959).

The Holy Bible, English Standard Version (London: HarperCollins Religious, 77-85 Fulham Palace Road, HammerSmith, W6 8JB, England. ESV® Text Edition: 2011). 